\title{
Coherent emission from the stack of Josephson junctions with the non-uniform inductive interaction
}

\author{
O.M. Grib ${ }^{1}$, O.L. Samsonik ${ }^{1}$, R.V. Sukhov ${ }^{2}$ \\ 1 Physics Department, V.N. Karazin Kharkiv National University, Svobody sq. 4, 61022 Kharkiv, Ukraine \\ 2 Department of Physics and Energy, Kharkiv V. N. Karazin National University, Svobody sq. 6, 61022 Kharkiv, Ukraine \\ alexander.gryb@googlemail.com
}

ORCID: 0000-0001-5772-9861, 0000-0002-3174-776X, 0000-0001-6952-6332

DOI:10.26565/2222-5617-2019-31-09

During last decade, considerable efforts were made to achieve coherent emission from stacks of many Josephson junctions. It is known that strong emission from a junction in the presence of external magnetic field appears at the so-called Fiske steps in the IV-characteristic at voltages which correspond to frequencies of geometrical resonances. However, it is possible to obtain resonant steps in long junctions without external magnetic field. The periodical movement of fluxons is excited due to some disorder in the distribution of critical currents along junctions. The so-called zero-field steps are formed in the IV-curve due to the interaction of fluxons with oscillations of voltage at Josephson frequencies. We investigated numerically IV-characteristics and the dependence of the average square of ac voltage at the end of the stack of two long Josephson junctions on the average voltage. Junctions interacted inductively with each other. We introduced not only the Gaussian distribution of critical currents along junctions but also the Gaussian distribution of coefficients of the interaction between junctions (mutual inductances). Zero-field steps in the IVcharacteristic were found at voltages which corresponded to frequencies of in-phase collective modes in the stack as well as to frequencies of uncoupled junctions. Zero-field steps appeared in the hysteretic region of the IV-curve. There appeared also jumps of voltage from the resistive branch to the zero-field step. We showed that there existed distributions of mutual inductances along junctions which provided jumps to voltages at which the average square of ac voltage at the end of the stack (which is proportional to power of emission) was larger than that for the stack with the uniform distribution of mutual inductances.

Keywords: coherent emission, zero-field steps. Josephson junctions, inductive interaction.

\section{Когерентна емісія пачок контактів Джозефсона з неоднорідною індуктивною взаємодією О.М. Гриб, О.Л. Самсонік, Р.В. Сухов \\ Харківський національний університет імені В.Н. Каразіна, м. Свободи 4, 61022, Харків, Україна}

Протягом останнього десятиліття значні зусилля були зроблені для досягнення когерентної емісії пачок багатьох контактів Джозефсона. Відомо, що сильна емісія від одного контакту в присутності зовнішнього магнітного поля досягається на так званих сходинках Фіске на вольт - амперній характеристиці при напругах, які відповідають частотам геометричних резонансів. Однак, можливо отримати резонансні сходинки в довгих контактах без зовнішнього магнітного поля. Періодичний рух флуксонів збуджується завдяки деякій невпорядкованості в розподілі критичних струмів вздовж контактів. Так звані сходинки нульового поля формуються на вольт - амперній характеристиці завдяки взаємодії флуксонів з осциляціями напруги на джозефсонівських частотах. Ми чисельно дослідили вольт-амперні характеристики та залежність усередненого квадрату змінної напруги на кінці пачки двох довгих контактів Джозефсона від усередненої напруги. Контакти взаємодіють індуктивно один $з$ одним. Ми ввели не тільки гаусівський розподіл критичних струмів вздовж контактів, але також гаусівськй розподіл коефіцієнтів взаємодії між контактами (взаємних індуктивностей). Сходинки нульового поля на вольт-амперній характеристиці були знайдені при напругах, які відповідають частотам як синфазних колективних мод у пачці, так і частотам відокремлених один від одного контактів. Сходинки нульового поля з'явилися у гістерезисному регіоні вольт-амперної характеристики. Стрибки напруги з резистивної гілки на сходинку нульового поля виникли на вольт-амперній характеристиці. Ми показали, що існують розподіли взаємних індуктивностей вздовж контактів, які забезпечують стрибки до напруг, при яких усереднений квадрат змінної напруги на кінці контакту (який пропорційний потужності емісії) є більшим, ніж для пачки з однорідним розподілом взаємних індуктивностей.

Ключові слова: когерентна емісія, сходинки нульового поля, контакти Джозефсона, індуктивна взаємодія. 
Когерентная эмиссия пачек контактов Джозефсона с неоднородным

индуктивным взаимодействием

\author{
А.Н. Гриб, А.Л. Самсоник, Р.В. Сухов \\ Харьковский национальный университет имени В.Н. Каразина, м. Свободы 4, 61022, Харьков, Украина
}

На протяжении последнего десятилетия были приложены значительные усилия для достижения когерентной эмиссии пачек многих джозефсоновских переходов. Известно, что сильная эмиссия от одного перехода в присутствии внешнего магнитного поля достигается на так называемых ступеньках Фиске на вольт - амперной характеристике при напряжениях, которые соответствуют частотам геометрических резонансов. Однако, возможно получить резонансные ступеньки в длинных контактах без внешнего магнитного поля. Периодическое движение флуксонов возбуждается благодаря некоторой неупорядоченности распределения критических токов вдоль переходов. Так называемые ступеньки нулевого поля формируются на вольт - амперной характеристике благодаря взаимодействию флуксонов с осцилляциями напряжения на переходах. Мы численно исследовали вольт - амперные характеристики и зависимость среднего квадрата переменного напряжения на конце пачки из двух длинных джозефсоновских переходов от усреднённого напряжения. Переходы индуктивно взаимодействуют друг с другом. Мы ввели не только гауссово распределение критических токов вдоль переходов, но также и гауссово распределение коэффициентов взаимодействия между переходами (взаимных индуктивностей). Ступеньки нулевого поля на вольт - амперной характеристике были найдены при напряжениях, которые соответствуют частотам как синфазных коллективных мод в пачке, так и частотам разъединённых переходов. Ступеньки нулевого поля появились в гистерезисном регионе вольт - амперной характеристики. Также на вольт - амперной характеристике возникли скачки напряжения с резистивной ветви на ступеньку нулевого поля. Мы показали, что существуют распределения взаимных индуктивностей вдоль переходов, которые обеспечивают прыжки к тем напряжениям, при которых средний квадрат переменного напряжения на конце перехода (он пропорционален мощности эмиссии) больше, чем для пачки с неоднородным распределением взаимных индуктивностей.

Ключевые слова: когерентная эмиссия, ступеньки нулевого поля, джозефсоновские переходы, индуктивное взаимодействие.

\section{Introduction}

One of the most important applications of the ac Josephson effect is the development of powerful emitters of high-frequency radiation from many Josephson junctions. To achieve this aim, special schemes of highfrequency connections between junctions were applied [1]. One of these schemes is based on the use of coherent modes in the stack of junctions placed in external magnetic field which is parallel to the interfaces of layers [2]. If the thickness of each of the superconducting layers $q$ is larger than two London depths of penetration of magnetic field in these layers $\lambda_{L}$, junctions are separated and voltages over different junctions oscillate independently. However, if $q<2 \lambda_{L}$ then circulated currents of neighbor junctions in each of the superconducting layers are superposed and junctions interact with each other. Due to this interaction, oscillations of voltages on individual junctions are transformed to normal modes just like it appears in coupled pendula, coupled LC-contours or vibrations of atoms in the solid [2]. Amongst these normal modes there always is the so-called in-phase mode, i.e. the mode in which all voltages over junctions oscillate in-phase. This in-phase mode interacts with standing waves which appear at frequencies of geometrical resonances of the system and as a result of this interaction resonant Fiskelike steps appear in IV-characteristic of the stack [2, 3]. There is strong coherent emission from the stack at these steps.

Further investigations of coupled junctions in a stack showed that magnetic field is not required for the formation of coherent modes as well as for the formation 60 Вісник ХНУ імені В.Н. Каразіна, серія «Фізика», вип. 31, 2019 of resonant steps $[4,5]$. In junctions with inhomogeneous distribution of critical currents, interacting circulated currents appear due to different drops of voltages in neighbor parts of the same junctions, and normal modes are excited in the stack [5]. Resonant steps in the IVcharacteristics in this case are called zero-field steps [6, 7]. There is also strong emission at zero-field steps which correspond to the coupling of the in-phase mode with standing waves [4].

In the present paper we investigate the formation of zero-field steps in IV-curves of the stack of two long junctions (i.e. junctions which have the length that is larger than the Josephson length of penetration of magnetic field) in the presence of the disorder of both critical currents and coefficients of the interaction between circulated currents in the stack. It was shown that these coefficients can be described as mutual inductances $L_{f}$ between junctions [4]. We show that in such a system there are as collective modes of voltage oscillations as modes of non-coupled voltage oscillations. Jumps of voltage from the resistive branch to the zero-field step appear in the hysteretic region of IV-characteristic. We show that there exist some distributions of $L_{f}$ along junctions which provide jumps to voltages at which coherent emission is stronger than that for the stack with the uniform distribution of $L_{f}$.

\section{The model}

For calculations we used the scheme of two inductively interacting long Josephson junctions which was described elsewhere [4, 5, 8], so here we give only its brief description. According to this scheme, each of long 
junctions with indices $i=1,2$ is divided to $n$ segments. Junctions in segments are described by the capacitively and resistively shunted model, so each of these junctions has its own capacitance $C_{i, j}$, the resistance $R_{j}$ and the source of Josephson current $I_{c \mathrm{j}} \cdot \sin \varphi_{i, j}$ (here $j=1 \ldots n$ is the number of the segment and $\varphi_{i, j}$ is the difference of the phase of the order parameter across the junction with indices $i$ and $j$ ). Junctions are connected by inductances $L$ in such a way that the relation $c^{\prime 2} L C_{a v}=\xi^{2}$ is valid (here $c^{\prime}$ is the velocity of light in the long junction, $C_{a v}$ is the averaged capacitance and $\xi$ is the linear size of the segment). Segments of different long junctions interact with each other by means of mutual inductances $L_{f i, j-1, j}$, where indices $j-1$ and $j$ relate to the segment between junctions with these indices. Then dynamic equations describing the behaviour of each of the phase difference $\varphi_{i, j}$ together with magnetic flux quantization conditions are as follows:

$$
\begin{gathered}
\alpha_{i, j} \frac{d^{2} \phi_{i, j}}{d t^{2}}+\beta_{i, j} \frac{d \phi_{i, j}}{d t}+I_{c i, j} \sin \phi_{i, j}=, \\
=I_{b}-I_{i, j-1, j}+I_{i, j, j+1} \\
L I_{1, j-1, j}-L_{f 2, j-1, j} I_{2, j-1, j}= \\
=-\frac{\Phi_{0}}{2 \pi}\left[\phi_{1, j-1}-\phi_{1, j}\right], \\
-L_{f 1, j-1, j} I_{1, j-1, j}+L I_{2, j-1, j}-= \\
=-\frac{\Phi_{0}}{2 \pi}\left[\phi_{2, j-1}-\phi_{2, j}\right],
\end{gathered}
$$

where $\quad I=1,2 ; \quad j=1 \ldots n, \quad \alpha=\Phi_{0} C_{i, j} /(2 \pi)$, $\beta_{i, j}=\Phi_{0} /\left(2 \pi R_{i, j}\right)$ with $\Phi_{0}$ is the quantum of magnetic flux, $I_{i, j-1, j}$ are circulating currents flowing between junctions with indices $i, j-1$ and $i, j$. Equations (1)-(3) must be supplemented with two pairs of boundary conditions (one pair for each of the long junctions), so we added two more fictive segments with indices $j=0, n+1$ at edges of each of the long junctions and stated boundary conditions for the transmission line with open ends:

$$
I_{i, 0,1}=0 ; I_{i, n, n+1}=0, i=1,2 \text {. }
$$

The system of equations (1)-(4) is different from that which we used in our previous calculations [4, 5, 8]. Due to inequality of coefficients $L_{f i, j-1, j}$, phase differences $\varphi_{i, j}$ obtain additions besides additions due to inequality of critical currents and resistances of segments. It is precisely the influence of such additions on IV- characteristic of the system and its emission that is investigated in the present paper.

We calculated values of averaged voltages over the system

$$
V=\frac{1}{M \cdot n} \frac{\Phi_{0}}{2 \pi}\left\langle\sum_{j=1}^{n}\left(\frac{d \phi_{1, j}}{d t}+\frac{d \phi_{2, j}}{d t}\right)\right\rangle
$$

with $M=2$ is the quantity of long junctions and angle brackets mean averaging on time. The averaged square of voltage $U^{2}{ }_{1}$ at the left end of the system (which is proportional to the power of emission from this end) is equal to

$$
U_{1}^{2}=\frac{\Phi_{0}}{2 \pi}\left\langle\left[\left(\frac{d \phi_{1,1}}{d t}-\left\langle V_{1,1}\right\rangle\right)+\left(\frac{d \phi_{2,1}}{d t}-\left\langle V_{2,1}\right\rangle\right)\right]^{2}\right\rangle
$$

where $\left\langle V_{1,1}\right\rangle=\left(\Phi_{0} / 2 \pi\right)\left\langle d \phi_{1,1} / d t\right\rangle$ is the average voltage over the junction with indices $i=1, j=1$. Note that for the averaged square of voltage at the right end of the system one should change indices 1,1 and 2,1 to $1, n$ and $2, n$ in the right part of Eq. (6).

We solved the system (1)-(4) by the method of RungeKutta. Values of $I_{c i, j}$ and $L_{f i, j-1, j}$ were set randomly with the use of Gaussian distribution with different values of the mean-square-root deviation $\sigma_{I}=\delta_{I} \cdot I c_{0}$ and $\sigma_{L}=\delta_{L} \cdot L_{f 0}$ with $I_{c 0}$ and $L_{f 0}$ are averaged values of critical currents and mutual inductances, correspondingly, so Values of resistances $R_{i, j}$ were calculated from the expression $R_{i, j}=V_{c} / I_{c i, j}$, where $V_{c}$ is the characteristic voltage set the same for all segments. In the following consideration we will use normalized units $u_{1}^{2}=U^{2}{ }_{1} / V c^{2}$ for the averaged square of voltage $U^{2}{ }_{1}$ at the left end of the system, $v=\langle V\rangle / V_{c}$ for the averaged voltage over the junction and $i_{b}=I_{b} / I_{c 0}$ for the bias current.

For calculations we set the length of the system $D=$ $6 \cdot 10^{-5} \mathrm{~m}$, the fictive width of the system $W=1 \cdot 10^{-4} \mathrm{~m}$, the critical current density $J_{c}=4 \cdot 10^{6} \mathrm{~A} / \mathrm{m}^{2}$ and the characteristic voltage $V_{c}=2 \cdot 10^{-3} \mathrm{~V}$. The obtained critical current of the system is equal to $I_{c t o t}=n \cdot I_{c 0}=24 \mathrm{~mA}$. Then we set the capacitance per unit square $C_{u s}=\varepsilon_{0} \cdot \varepsilon / d$, where $\varepsilon_{0}=8.854 \cdot 10^{-12} \mathrm{~F} / \mathrm{m}, \varepsilon=2$ and the thickness of the barrier $d=2 \cdot 10^{-9} \mathrm{~m}$. The average value of the velocity of light in the long junction $c^{\prime}$ was obtained with the use of the expression $c^{\prime}=c_{0} \cdot[d /(\varepsilon \cdot q)]^{1 / 2}[6]$, where $c_{0}$ is the velocity of light in vacuum and $q=2 \cdot \operatorname{cth}\left(z / \lambda_{L}\right)+d$ with $z$ is the thickness of the superconducting layer $\lambda_{L}$ is the London depth of penetration. We used $z=2 \cdot 10^{-8} \mathrm{~m}$ and $\lambda_{L}=4 \cdot 10^{-8} \mathrm{~m}$ and obtained $c^{\prime}=2.265 \cdot 10^{7} \mathrm{~m} / \mathrm{sec}$. Then we divided the long junction to $n$ segments and obtained the set of parameters of segments such as $\xi, L, I_{c 0}$ etc. The averaged value of the mutual inductance was equal to $0.35 \cdot L$. 


\section{Results and Discussion}

The IV-characteristic for the system with random distributions for critical currents $\delta_{I}=10^{-6}$ and $\delta_{L}=0.3$ for values of $L_{f i, j}$ is shown in Fig. 1. It is seen that there are a set of zero-field steps in the IV-characteristic. Steps at $v_{p=1}=0.2$ and $v_{p=2}=0.4$ correspond to the first $(p=1)$ and the second $(p=2)$ geometrical resonances in the system $v_{p}=\left(\Phi_{0} \cdot c^{\prime} \cdot p /(2 \cdot D)\right.$, whereas steps at $v_{p=1, s}=0.24, v_{p=2, s}=0.49$ and $v_{p=3, s}=0.49$ correspond to in-phase resonances of normal modes at steps with $p=1, \quad p=2$ and $p=3$, correspondingly. Positions of steps we marked by arrows in Fig. 1. Equations for positions of these zero-field steps are as follows: $v_{p, s}=v_{p} /\left[1-\left(L_{f 0} / L\right)\right]^{1 / 2}[4]$. Thus, collective modes as well as non-coupled modes exist in the system. It is interesting to note that instead of the step at $v_{p=2, s}=0.49$ there exists the long jump to smaller voltages. This jump appears because of the hysteretic behavior of the IV-curve in the region of the zero-field step at the backward movement of the bias current [8]. Jumps in the IV-curve as well as steps show the presence of resonance particularities.

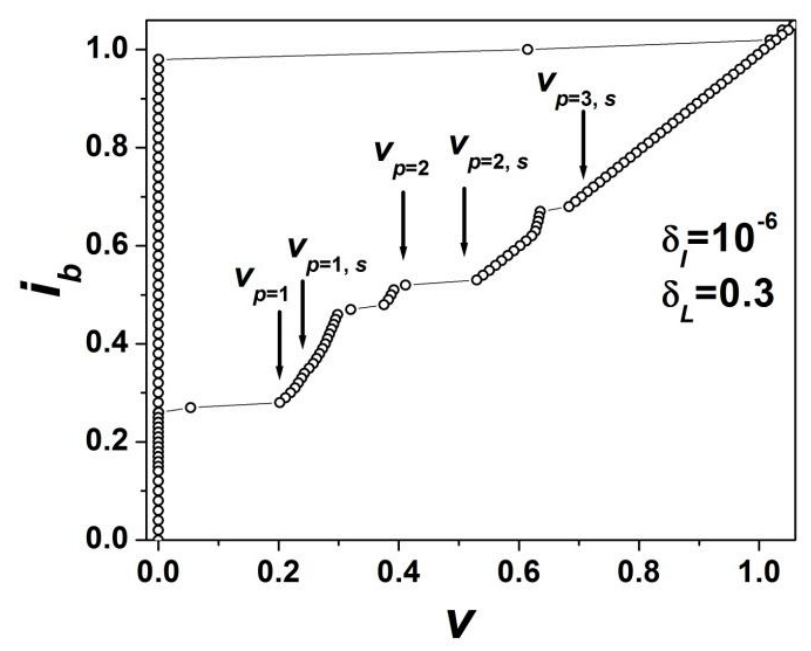

Fig. 1. The IV-characteristic of the stack of two Josephson junctions with the Gaussian distributions $\delta_{I}=10^{-6}$ and $\delta_{L}=0.3$. Arrows show positions of zero-field steps.

The averaged square of voltage at the left end of the system for $n=60, \delta_{I}=10^{-6}$ and $\delta_{L}=0$ is shown in Fig. 2 (triangles). We also showed data (circles in Fig. 2) obtained for fourteen different random realizations of the stack with $\delta_{L}=0.3$ but with the same relief of the distribution of bias currents along junctions calculated only one time with $\delta_{I}=10^{-6}$. Maxima in Fig. 2 correspond to $v_{p=1}=0.2, v_{p=2}=0.4, v_{p=1, s}=0.24, v_{2, s}=0.49$ and $v_{3, s}=0.72$ that is characteristic of the in-phase synchronization. It is important to note that for junctions in the stack the mean Josephson length of penetration of magnetic field $\lambda_{J}$ is equal to $1.9 \cdot 10^{-5} \mathrm{~m}$, so the condition $D>\lambda_{J}$ is valid. The so-called Fulton-Dynes mechanism of the movement of fluxons appears at frequencies of geometrical resonances [9]. The coherent movement of fluxons in stack of junctions in magnetic field was considered in Ref. [10]. In our calculations maxima of $u_{1}^{2}$ at $v_{p, u}$ in Fig. 2 correspond to the interaction of fluxons with the collective modes without magnetic field.

It is seen from Fig. 2 that due to randomization of mutual inductances the large zero-field step at $v_{p=2, s}=0.49$ can be shown in full. Maxima of $u_{1}^{2}$ for some realizations of the random distribution of mutual inductances are higher than those for $\delta_{L}=0$ (see Fig. 2). This does not mean that there exist random realizations of mutual inductances which provide stronger emission at this zerofield step than that for the case $\delta_{L}=0$. Due to the hysteresis of the IV-curve in the range of the zero-field step, there is the jump of voltage from the resistive branch to some voltage of the zero-field step. The value of this voltage was up to now considered as arbitrary. However, our data showed that at some distributions of mutual inductances jumps of voltage appeared to the very top of the zero-field step. Objective laws of jumps of voltage at zero-field steps should be investigated in details in further investigations for obtaining of maximal emission from the stack.

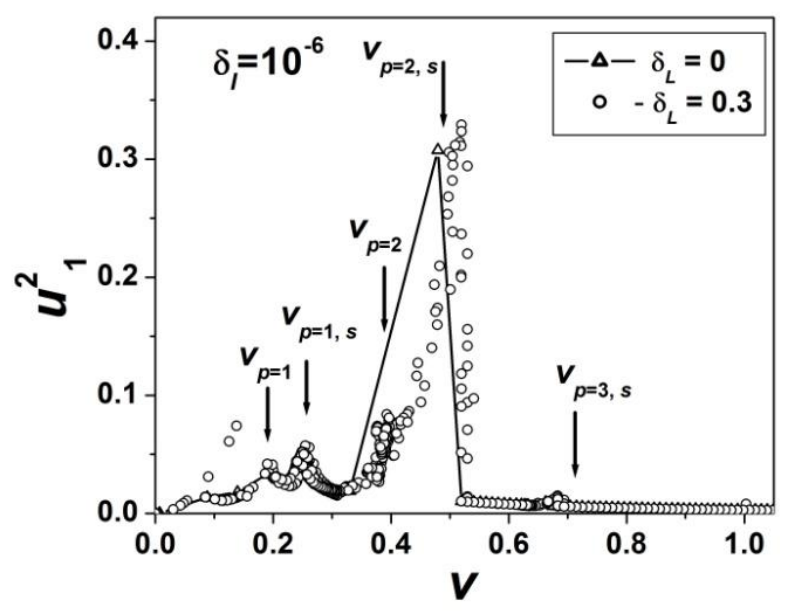

Fig. 2. The dependence $u^{2}{ }_{1}$ on the normalized averaged voltage for the system with $\delta_{I}=10^{-6}$ and $\delta_{L}=0$ (triangles, solid line) and for fourteen realizations with $\delta_{I}=10^{-6}$ and $\delta_{L}=0.3$ (circles). Arrows show positions of zero-field steps.

\section{Conclusions}

In the present paper we investigated IV-characteristics and the averaged square of ac voltage at the edge of the stack $u_{1}^{2}$ of two long Josephson junctions with the random inductive interaction between junctions. Values of $u_{1}{ }_{1}$ are proportional to power of emission. We found zero-field steps in the IV-characteristic of the stack. These zero-field steps correspond to the first, second and third geometrical resonances in the system. We calculated values of $u_{1}^{2}$ at different random distributions of the 
parameter of the inductive interaction along junctions. We found that there are distributions of mutual inductances at which values of $u_{1}^{2}$ at zero-field steps are large than those for the homogeneous distribution of mutual inductances.

\section{References}

1. K. K. Likharev. Dynamics of Josephson junctions and circuits, Gordon and Breach, Philadelphia. (1991), 750 p.

2. S. Sakai, A. V. Ustinov and H. Kohlstedt, A. Petraglia and N. F. Pedersen, Phys. Rev. B, 50, 12905 (1994).

3. R. Kleiner, P. Müller, H. Kohlstedt. N. F. Pedersen, S. Sakai, Phys. Rev.B, 50, 3942 (1994).

4. Alexander Grib, Paul Seidel and Masayoshi Tonouchi, Supercond. Sci. Technol., 30, 014004 (2017).

5. Alexander Grib and Paul Seidel. IEEE Trans. Appl. Supercond. 26, №3, 1801004 (2016).

6. Antonio Barone, Gianfranco Paternò. Physics and applications of the Josephson effect, John Wiley and sons, New York. (1982), 529 pp.

7. C. Camerlingo, M. Russo, R. Vaglio, J. Appl. Phys., 53, 7609 (1982).

8. Alexander Grib,Sergiy Savich, Ruslan Vovk, Volodymyr Shaternik, Andrii Shapovalov, Paul Seidel. IEEE Trans. All. Supercond. 28, № 7, 1801106 (2018).

9. T. A. Fulton and R. C. Dynes. Solid State Commun., 12, 57 (1973).

10. N. F. Pedersen and S. Madsen. Supercond. Sci. Technol., 17, №5, pp.S117 (2004). 